\title{
Володимир ТИТОР
}

викладач кафедри податків та фріскальної політики, Західноукраїнський національний університет, Тернопіль, Україна, v.tytor@gmail.com

ORCID ID: 0000-0002-2039-3716

\section{Віктор ЗАЯЦ}

старший науковий співробітник відділу удосконалення протидії митним правопорушенням, Науково-дослідний центр митної справи Науково-дослідного інституту фріскальної політики Університету Державної фріскальної служби України, Ірпінь, Україна, zуjсis@gmail.com ORCID ID: 0000-0003-4840-0823

\section{Irop KEKIШ}

викладач кафредри податків та фріскальної політики, Західноукраїнський національний університет, Тернопіль, Україна, kekishihor@gmail.com

ORCID ID: 0000-0003-1798-3130

\section{ОРГАНІЗАЦЙНО-СТРУКТУРНЕ ЗАБЕЗПЕЧЕННЯ ОПЕРАТИВНО-РОЗШУКОВОї ДІЯАЫНОСТІ МИТНИХ ОРГАНIB}

\begin{abstract}
Вступ. Розглянуто питання щодо надання митним органам України права на оперативно-розшукову діяльність (ОРД) з метою покращення протидії та виявлення порушень митного законодавства, які становлять загрозу економічним, соціальним і фріскальним інтересам держави та законним інтересам торгівлі. Досліджено правові норми та директиви міжнародних організацій, членом яких $є$ Україна, та міжнародних угод, ратифрікованих Україною, проведено порівняння з національним законодавством. Запропоновано переглянути чинне українське законодавство з митної справи в напрямку боротьби 3 контрабандою та порушеннями митних правил, привести його до міжнародних норм та надати митним органам права на ОРД як повноцінному правоохоронному органу. Запропоновано завдання і показники їх досягнення з організаційного забезпечення ОРД в митній службі України та структуру правоохоронних підрозділів митної служби України.

Мета - проаналізувати міжнародні правові акти з митної справи, які вказують на необхідність надання митним органам України ОРД з метою виконання ними своїх функцій у напрямку боротьби з контрабандою та порушеннями митних правил, в повному обсязі та більш ефективно. Це право необхідне митним органам не лише для протидії та запобігання проявам контрабанди, а й для результативної взаємодії з митними $i$ правоохоронними органами інших держав.

Meтоди. У статmі під час дослідження організаційно-структурного забезпечення оперативно-розшукової діяльності митних органів застосовано методи аналізу, порівняння та синтезу.
\end{abstract}

(с Володимир Йосипович Титор, Віктор Віталійович Заяц, Ігор Петрович Кекіш, 2020 
Результати. Виявлено та систематизовано недоліки щодо інституційної спроможності у сорері правоохоронної діяльності митної служби України, зокрема відсутністю ОРД у вітчизняних митних органів, що дало змогу визначити иляхи та перспективи їх подальшого впровадження. Особливу увагу приділено потребі синхронізації положень українського законодавства з відповідними нормами міжнародних угод, чинних для України, та інших, нератифрікованих Україною, з цього питання.

Перспективи. Подальші наукові дослідження стосовно інституційної спроможності у ссрері правоохоронної діяльності митної служби України, в напрямку організаційно-структурного забезпечення оперативно-розшукової діяльності митних органів, доцільно проводити на основі сформованого теоретичного обгрунтування складу їі правоохоронних повноважень із урахуванням рівнів офріційної взаємодії - відомчого, міжвідомчого, міжнародного.

Ключові слова: митна справа, митні органи, митна служба, митні прототипи, порушення митних правил, контрабанда, митні правопорушення.

Табл.: 1, бібл.: 11.

\section{Владимир ТЫТОР}

преподаватель кафредры налогов и фрискальной политики, Западноукраинский национальный университет, Тернополь, Украина

\section{Виктор ЗАЯЦ}

старший научный сотрудник отдела усовершенствования противодействия таможенным правонарушениям, Научно-исследовательский центр таможенного дела Научно-исследовательского института фрискальной политики Университета Государственной фрискальной службы Украины, Ирпень, Украина

\section{Игорь КЕКИШ}

преподаватель кафредры налогов и фрискальной политики, Западноукраинский национальный университет, Тернополь, Украина

\section{ОРГАНИЗАЦИОННО-СТРУКТУРНОЕ ОБЕСПЕЧЕНИЯ ОПЕРАТИВНО- РОЗЫСКНОЙ ДЕЯТЕАЬНОСТИ ТАМОЖЕННЫХ ОРГАНОВ}

Введение. Рассмотрено предоставление таможенным органам Украины права на оперативно-розыскную деятельность (ОРД) с целью улучшения противодействия и выявления нарушений таможенного законодательства, которые составляют угрозу экономическим, социальным и фискальным интересам государства и законным интересам торговли. Исследовано правовые нормы и директивы международных организаций, членом которых является Украина, и международных соглашений, ратифрицированных Украиной, проведено сравнение с национальным законодательством. Предложено пересмотреть действующее украинское законодательство по таможенному делу по борьбе с контрабандой и нарушениями таможенных правил, привести его к международным нормам и предоставить таможенным органам право на ОРД как полноценному правоохранительному органу. Предложено задачи и показатели их достижения с организационного обеспечения ОРД в таможенной службе Украины и примерную структуру правоохранительных подразделений таможенной службы Украины.

Цель - провести анализ международных правовых актов по таможенному делу, которые указывают на необходимость предоставления таможенным органам Украины 
ОРД с целью выполнения ими свочх функций по борьбе с контрабандой и нарушениями таможенных правил, в полном объеме и более эфективно. Это право необходимо таможенным органам не только для противостояния и предотвращения проявлениям контрабанды, но и для результативного взаимодействия с таможенными и правоохранительными органами других государств.

Методы. В статье во время исследования организационно-структурного обеспечения оперативно-розыскной деятельности таможенных органов применены методы анализа, сравнения и синтеза.

Результаты. Выявлены и систематизированы недостатки относительно институциональной способности в сфрере правоохранительной деятельности таможенной службы Украины, в частности отсутствие ОРД в отечественных таможенных органов. Особое внимание уделено необходимости синхронизации положений украинского законодательства с соответствующими нормами международных соглашений, действующими для Украины, и других, нератифицированных Украиной, по данному вопросу.

Перспективы. Дальнейшие научные исследования относительно институциональной способности в сорере правоохранительной деятельности таможенной службы Украины, в направлении организационно-структурного обеспечения оперативно-розыскной деятельности таможенных органов, иелесообразно проводить на основе сфрормированного теоретического обоснования состава ее правоохранительных полномочий с учетом уровней официального взаимодействия - ведомственного, межведомственного, международного.

Ключевые слова: таможенное дело, таможенные органы, таможенная служба, таможенные прототипы, нарушение таможенных правил, контрабанда, таможенные правонарушения.

\section{Volodymyr TYTOR}

Lecturer at the Department of Data and Fiscal Policy, West Ukrainian National University,

Ternopil, Ukraine, v.tytor@gmail.com

ORCID ID: 0000-0002-2039-3716

\section{Victor ZAIATS}

Senior Research Scholar, Department for the Improvement of Counteraction to Customs Offenses, Scientific Research Center for Customs Affairs Research Institute of Fiscal Policy University o f the State Fiscal Service of Ukraine, Irpin, Ukraine, zyjcis@gmail.com

ORCID ID: 0000-0003-4840-0823

\section{Ihor KEKISH}

Lecturer at the Department of Data and Fiscal Policy, West Ukrainian National University,

Ternopil, Ukraine, kekishihor@gmail.com

ORCID ID: 0000-0003-1798-3130

\section{ORGANIZATIONAL AND STRUCTURAL SUPPORT OF OPERATIONAL AND SEARCH ACTIVITIES OF CUSTOMS AUTHORITIES}

Introduction. The issue of granting the customs authorities of Ukraine the right to operational-search activities (OSA), in order to improve the fight against and identify violations of customs legislation that threaten the economic, social and fiscal interests of the state and the 
legitimate interests of trade are analized. On this task, the legal norms and directives of international organizations of which Ukraine is a member and international agreements ratified by Ukraine were studied, and a comparison with our legislation was made. It is proposed to revise the current Ukrainian legislation on customs in the direction of combating smuggling and violations of customs rules, bring it into line with international standards and give customs authorities the right to the OSA as a full-fledged law enforcement agency. The tasks and indicators of their achievement on organizational support of the OSA in the Customs Service of Ukraine and the approximate structure of law enforcement units of the Customs Service of Ukraine are offered.

The purpose of the article is to analyze international legal acts on customs, which indicate the need to provide the customs authorities of Ukraine with OSA in order to perform their functions in the fight against smuggling and violations of customs rules, in full and more effectively. This right is necessary for customs authorities not only to counter and prevent smuggling, but also for effective cooperation with customs and law enforcement agencies of other states.

Methods. The methods of analysis, comparison and synthesis during the study of organizational and structural support of operational-search activities of customs authorities were used.

Results. The main scientific result of the article is to identify, related to the terms of institutional capacity in the field of law enforcement of the Customs Service of Ukraine were identified and systematized, in particular, the lack of OSA in domestic customs authorities, which allowed to identify ways and prospects for their further implementation. Particular attention is paid to the need to synchronize the provisions of Ukrainian legislation with the relevant provisions of international agreements in force for Ukraine and other non-ratified by Ukraine on this issue.

Perspectives. Further research on the institutional capacity in the field of law enforcement of the Customs Service of Ukraine, in the direction of organizational and structural support of operational-search activities of customs authorities, should be conducted on the basis of theoretical justification of its law enforcement powers, taking into account levels of official interaction departmental, interagency, international.

Keywords: custom affair, customs authorities, Custom Service of Ukraine, customs blueprints, violation of customs rules, smuggling, customs offenses.

JEL Classification: H26, K34.

Постановка проблеми. Сучасному світові притаманне динамічне зростання обсягів міждержавної торгівлі, а також міжнародних транспортних перевезень пасажирів і вантажів. За таких обставин митні органи країн перебувають на передній лінії боротьби з транскордонними правопорушеннями, особливу небезпеку серед яких становлять контрабанда зброї, боєприпасів, отруйних, сильнодіючих, вибухових речовин, радіоактивних матеріалів, наркотичних засобів, психотропних речовин, їх аналогів й прекурсорів, а також комерційні шахрайства, пов'язані з незаконним переміщенням через митний кордон культурних цінностей, контрафактних товарів, високооподатковуваних товарів, таких як сигарети, алкогольні напої, брендові товари, ін. Результативність цих заходів залежить від обсягу правоохоронних повноважень, якими, відповідно до положень законодавства, наділені митні органи держави. В зв'язку 3 цим зростає потреба у дослідженні митного правозастосування та подальшому його 
удосконаленні, зокрема - надання митним органам України оперативно-розшукової діяльності (ОРД).

Аналіз останніх досліджень і публікацій. Про необхідність надання митним органам України повноважень щодо здійснення ОРД, як однієї із основних складових правоохоронної діяльності, у своїх працях зазначають науковці К. Антонов [1], В. Варава [1], О. Разумова [2], Л. Дорофеєева [3], Є. Додін, В. Орлов, Д. Приймаченко, А. Уліцький.

Зокрема, у працях К. В. Антонова і В. В. Варави акцентовано на необхідності збільшення повноважень митних органів, а саме - надання їм права здійснювати ОРД і досудове слідство, висвітлено сучасний стан, проблеми, причини і тенденції з цього питання, також вказується на необхідності отримання статусу судово-експертних установ - митними лабораторіями. Необхідність збільшення обсягу названих повноважень, згідно з дослідженнями науковців, обумовлюється практикою, яка склалась у багатьох економічно розвинутих країнах; переміщенням через митний кордон України великих обсягів контрабанди; недоречністю покладання на митні органи відповідальності за боротьбу із контрабандою без забезпечення їх відповідними можливостями та інструментарієм; унеможливленням повноцінного обміну інформацією між митними органами та іншими, уповноваженими на ОРД, органами [1].

О. Разумова доводить необхідність надання повноважень зі здійснення ОРД Держмитслужбі України, відповідному профільному департаменту з боротьби з митними правопорушеннями. До такого висновку дослідниця дійшла, опрацювавши: відповідні положення Митного кодексу $€ C$, в яких визначено права митних органів організовувати та реалізувати ОРД, пов'язану з отриманням, нагромадженням, обробкою та перевіркою інформації, що стосується зовнішньоторговельного товарообігу, можливістю секретного спостереження, використанням допомоги осіб, не задіяних у митній службі, а також правом на застосування засобів безпосереднього примусу у формі застосування фізичної сили та індивідуальних технічних і хімічних засобів або засобів, призначених для обеззброєння й конвоювання осіб; Рамкові стандарти Всесвітньої митної організації (ВМО) в контексті забезпечення обсягу, змісту і порядку митної безпеки США, Великобританії, Німеччини, Польщі [2].

Науковець Л. М. Дорофеєва доводить доцільність та обґрунтованість офріційного визнання митних органів правоохоронними, опираючись на аналіз функціонального навантаження захисного (правоохоронного) характеру митних органів, такого як контроль за дотриманням законодавства у сфері регулювання порядку здійснення зовнішньоекономічної діяльності, переміщенням транспортних засобів, товарів через митний кордон України, провадження у справах про порушення митних правил тощо, а також той фракт, що декриміналізація контрабанди та обмеження повноважень митних органів щодо реалізації ОРД насправді жодним чином не знизила їхньої активності у сфрері протидії злочинності. Відповідно до таких міркувань, науковець зробила висновок про необхідність законодавчого закріплення за митними органами України повноважень у сфері ОРД, зокрема шляхом прийняття відповідних нормативно-правових актів з питань: структурної реорганізації з метою створення підрозділу, уповноваженого на здійснення ОРД; впорядкування безпосередньої організації провадження негласних слідчих дій; створення умов для належного захисту інформації з обмеженим доступом [3].

Метою статті $€$ дослідження міжнародних правових норм, які регламентують 
порядок боротьби митних органів з правопорушеннями в митній сфері із застосуванням митними органами інших країн ОРД, як необхідної. Особливу увагу необхідно приділити потребі синхронізації положень українського законодавства з відповідними нормами міжнародних угод, чинних для України, а також директив і стандартів, які діють в ЄС з даного питання.

Виклад основного матеріалу дослідження. Питання ефективності боротьби митних органів 3 митними правопорушеннями перебуває в центрі уваги митних адміністрацій - учасників Всесвітньої митної організації (ВМО), членства в якій Україна набула в 1992 р. Зважаючи на це, Радою митного співробітництва - попередником ВМО - видано Резолюцію від 24 червня 1992 року “Щодо важливості розвідувальних даних для підтримки діяльності з митного правозастосування" [4].

У ній зазначено, що розвідка є важливим знаряддям для митних адміністрацій у боротьбі проти зростаючого комерційного шахрайства та незаконного обігу наркотиків, які мають міжнародний характер. При цьому наголошено на необхідності вдосконалення обміну розвідданими на національному, регіональному та міжнародному рівнях $з$ метою підвищення ефективності дій митних служб та забезпечення оптимального використання наявних у них ресурсів. Резолюція закликає країни-учасники ВMO посилити адміністративне й оперативне співробітництво, забезпечивши наявність необхідних адміністративних структур і процедур для активного формування інформації про всі види визначеного законодавством шахрайства, незаконний обіг наркотиків та торгівлю людьми.

У Резолюції Комісії з питань політики Всесвітньої митної організації "Про роль митниці в контексті безпеки" (Резолюція Пунта-Кана, грудень 2015) [5] ВМО визна- чає митні органи в усьому світі як фрорпост захисту проти багатьох кримінальних, екстремістських та терористичних організацій, які протиправним чином використовують міжнародні кордони. При цьому обмін розвідданими та тісна співпраця між митними органами й іншими правоохоронними органами для досягнення спільних цілей у контексті прикордонної безпеки вважаються ключовим елементом для ефективної нейтралізації цієї загрози.

Водночас Резолюція Пунта-Кана закликає митні адміністрації:

- внести питання транскордонної безпеки до своїх стратегічних планів, використовуючи це для розширення свого мандату та правоохоронних функцій;

- застосовувати увесь спектр сучасних прийомів виявлення та розслідування, включаючи профілювання ризиків, обмін розвідданими, контрольовані поставки, судово-медичну експертизу, пошукових собак та обладнання;

- використовувати повний обсяг закону для забезпечення належного рівня покарання, що діяло б як ефективний стримуючий фрактор;

- брати активну участь у правоохоронних операціях, вирішуючи проблеми, пов'язані з безпекою кордону;

- внести свій вклад у боротьбу з тероризмом, включаючи запобігання фрінансуванню тероризму через іншу незаконну діяльність.

Важливим напрямком організаційного забезпечення ОРД під час здійснення митної справи $€$ нарощування правоохоронної спроможності митних органів шляхом зміцнення законодавчого підґрунтя для застосування ними оперативно-розшукових заходів.

Варто наголосити, що, набуваючи в 2000-му участі в Міжнародній конвенції про взаємну адміністративну допомогу у відверненні, розслідуванні та припиненні по- 
рушень митного законодавства (Конвенція Найробі) [6], наша держава не приєдналася до Додатків IV, IX, X, XI цієї Конвенції, чим було обмежено підстави для здійснення ОРД митними органами України. Ми вважаємо, що для виправлення цієї ситуації необхідно долучити вказані Додатки до власного законодавчого поля, в результаті чого митні органи набудуть права на здійснення допомоги за запитом стосовно нагляду, збору інформації; надання допомоги у боротьбі з контрабандою наркотиків та психотропних речовин, у протидії контрабанді творів мистецтва, антикваріату та інших культурних цінностей.

У зазначеній Конвенції "порушення митного законодавства” означає будь-яке порушення або спробу порушення митного законодавства; "митне шахрайство" - порушення митного законодавства, за допомогою якого особа вводить митні органи в оману і, таким чином, уникає, повністю або частково, сплати імпортних або експортних мит та податків, чи виконання заборон і обмежень, встановлених митним законодавством, або отримує будь-яку вигоду в порушення митного законодавства; “контрабанда” означає митне шахрайство, що полягає у переміщенні товарів через митний кордон у будь-який прихований спосіб [6].

У Додатку IV Конвенції Найробі визначено, що у разі надання запиту митної адміністрації однієї Договірної Сторони митна адміністрація іншої Договірної Сторони в межах своїх можливостей та компетенції здійснює особливий нагляд у визначений період часу за переміщенням в межах ії території (в'їздом, виїздом) осіб, які підозрюються в тому, що вони постійно чи періодично здійснюють порушення митного законодавства на території запитуючої Договірної Сторони; за певними автомобілями, суднами, літаками та іншими транспортними засобами, які підозрюються у використанні для вчинення порушень митного законодавства на території запитуючої Договірної Сторони; за переміщеннями певних товарів, які за повідомленням митної адміністрації Договірної Сторони у значних обсягах незаконно переміщуються з/на її територію; за певними приміщеннями для складування товарів, щодо яких є підозра, що їх використовують для незаконного ввезення товарів на територію запитуючої Договірної Сторони.

Відповідно, до митної адміністрації запитуючої Договірної Сторони передається відповідний звіт про здійснений особливий нагляд.

Вказана діяльність із особливого нагляду відповідає, наданому пунктом 11 ст. 8 Закону України від 18.02.1992 № 2135-XII "Про оперативно-розшукову діяльність" (Закон про ОРД) [7], праву оперативним підрозділам здійснювати спостереження за особою, річчю або місцем.

Збір інформації, яка становить міжнародний інтерес, відповідно до Додатку IX Конвенції Найробі, здійснює її Секретаріат для внесення до центрального банку інформації, яку надають Договірні Сторони і використовують для підготовки узагальнень і навчальних посібників щодо нових і рецидивних напрямків здійснення митного шахрайства.

Генеральний секретар Ради Конвенції Найробі розповсюджує серед служб та посадових осіб, визначених митними адміністраціями Договірних Сторін, вищезгадані узагальнення та навчальні посібники, а також специфічну інформацію, що міститься у центральному банку, в обсязі, який він вважає необхідним. За запитом Договірних Сторін Генеральний секретар Ради надає їм будь-яку іншу наявну в нього інформацію.

Збір інформації, яка становить міжнародний інтерес, стосується відомостей про:

- осіб, які визнані винними у вчиненні контрабанди, підозрюваних у вчиненні 
контрабанди або затриманих у зв'язку з вчиненням контрабанди на території Договірної Сторони;

- осіб, остаточно визнаних винними у вчиненні митного шахрайства, що не $є$ контрабандою, а також підозрюваних у вчиненні такого шахрайства;

- методи вчинення контрабанди та інших видів шахрайства, включаючи способи приховування, фральсифрікації та підробки;

- транспортні засоби, задіяні для вчинення контрабанди.

Договірні Сторони повідомляють одна одній про нові, незвичні, можливі, та про кожне застосування відомих методів вчинення контрабанди й інших видів шахрайства та 3 метою виявлення сучасних тенденцій.

Про фрізичних осіб, які вчинили порушення митного законодавства, Генеральний секретар Ради Конвенції Найробі надає інформацію державам, громадянами яких вони є, державам їхнього проживання та державам, у яких вони перебували протягом попередніх 12 місяців.

Вказана діяльність зі збору та використання інфрормації відповідає, наданому пунктом 18 ст. 8 Закону про ОРД, праву оперативним підрозділам створювати і застосовувати автоматизовані інформаційні системи.

Згідно з Додатком X Конвенції Найробі, надання допомоги у боротьбі з контрабандою наркотиків та психотропних речовин, регламентовано, що митні адміністрації Договірних Сторін, з власної ініціативи і без затримки, передають митним адміністраціям, яких це безпосередньо стосується, та до Секретаріату Конвенції будь-яку наявну інформацію про вчинені або очікувані дії, які можуть призвести до контрабанди наркотичних засобів або психотропних речовин, осіб, причетних до вчинення або які підозрюються у вчиненні контрабанди наркотичних засобів або психотропних ре- човин, та про транспортні засоби, які використовувалися або підозрюються у використанні для вчинення таких дій, а також інфрормацію щодо нових способів та методів, включаючи способи приховування, які використовують для контрабанди наркотичних засобів, психотропних речовин та новітніх речовин і засобів, які використовують як наркотики або психотропні речовини і які є об'єктом контрабанди.

Генеральний секретар Ради Конвенції Найробі забезпечує внесення перелічених вище відомостей до центрального банку інформації, їхнє узагальнення, використання та розповсюдження.

Будь-яку інформацію щодо контрабанди наркотичних засобів і психотропних речовин, що міститься у центральному інформаційному банку, а також підготовлені з цього питання будь-які узагальнення та навчальні посібники, у разі відсутності заперечень з боку Договірної Сторони, що надає інфрормацію, Генеральний секретар Ради Конвенції розповсюджує в межах доцільного серед служб та посадових осіб, відповідних структур Організації Об'єднаних Націй та Міжнародної організації кримінальної поліції (Інтерпол) й інших міжнародних організацій, з якими щодо цього $€$ відповідні домовленості.

При наданні запиту митною адміністрацією однієї Договірної Сторони митна адміністрація іншої Договірної Сторони в рамках своєї компетенції та можливостей здійснює спеціальний нагляд за значними переміщеннями наркотичних засобів і психотропних речовин, переміщенням осіб, підозрюваних у контрабанді наркотичних засобів та психотропних речовин, складськими приміщеннями та транспортними засобами, щодо яких є підстави передбачати, що їх використовують для вказаної контрабанди. За результатами такого нагляду Договірна Сторона надає звіти до митної адміністрації запитуючої Договірної Сторони. 
В процесі надання запиту митною адміністрацією однієї Договірної Сторони митна адміністрація іншої Договірної Сторони, керуючись чинним законодавством на її території, з метою отримання доказів вчинення контрабанди наркотичних засобів або психотропних речовин згідно 3 розслідуванням, що проводиться на території запитуючої Договірної Сторони, здійснює опитування й отримує свідчення від будь-яких осіб, які можуть бути причетні до вчинення контрабанди, а також від свідків або експертів, та передає результати проведеного опитування митній адміністрації запитуючої Договірної Сторони разом з відповідними документами та доказами.

Посадові особи митної адміністрації однієї Договірної Сторони за запитом іншої Договірної Сторони можуть брати участь у розслідуваннях, що проводять на території іншої Договірної Сторони, за необхідності, якщо така встановлена обома Договірними Сторонами та з врахуванням законодавства обох Сторін.

Виконання дій з надання допомоги у боротьбі 3 контрабандою наркотиків та психотропних речовин, що передбачено Додатком X Конвенції Найробі, відповідає, наданому пунктом 20 ст. 8 Закону про ОРД, праву оперативним підрозділам звертатися у межах своїх повноважень із запитами до правоохоронних органів інших держав та міжнародних правоохоронних організацій.

Згідно з додатком XI Конвенції Найробі визначено надання допомоги у протидії контрабанді творів мистецтва, антикваріату та інших культурних цінностей, що аналогічно наданню допомоги у боротьбі з контрабандою наркотиків та психотропних речовин.

Слід зазначити, що чинні міжнародні договори України, згода на обов'язковість яких надана Верховною Радою України, є частиною національного законодавства і застосовуються у порядку, передбаченому для норм національного законодавства (ч. 1 ст. 19 Закону України від 29.06.2004 № 1906 “Про міжнародні договори України”) [8].

Якщо міжнародним договором України, згода на обов'язковість якого надана Верховною Радою України, встановлено інші правила, ніж ті, що передбачені Митним кодексом та іншими законами України, застосовуються правила міжнародного договору України, як це передбачено ч. 3 ст. 1 Митного кодексу України (МКУ) [9].

Згідно з Конвенцією Найробі Договірні Сторони погоджуються, що їх митні адміністрації надаватимуть одна одній взаємну допомогу з метою відвернення, розслідування та припинення порушень митного законодавства згідно з положеннями цієї Конвенції. Зміст такої допомоги передбачає застосування митними адміністраціями оперативно-розшукових заходів, наведених у Законі про ОРД .

Отже, приєднання України за встановленою процедурою до Додатків IV, IX, X, XI Конвенції Найробі організаційно забезпечуватиме набуття митними органами нашої держави повноважень на здійснення ОРД.

Помітно важливу роль у зміцненні правоохоронної спроможності митних органів відіграє визначений законодавством євроінтеграційний курс України. У зв'язку з цим наша держава має втілювати стандарти $€ C$, зокрема й ті, що трансформуватимуть правоохоронну діяльності ДМСУ.

Положення Угоди від 27.06.2014 про асоціацію між Україною, з однієї сторони, та Європейським Союзом, Європейським співтовариством з атомної енергії і їхніми державами-членами, з іншої сторони (далі Угода про асоціацію з ЄС) [10], що набула чинності з 01.09.2017 р., якраз зумовлюють потребу змін у правоохоронній складовій державної митної справи.

У статті 22 (“Боротьба зі злочинністю та корупцією") Угоди про асоціацію з ЄС 
встановлено, що 3 метою попередження кримінальної і незаконно організованої чи іншої діяльності та у боротьбі з нею Сторони співпрацюють. Така співпраця зумовлена і вирішенням проблемних питань щодо незаконного переміщення через державні кордони нелегальних мігрантів; незаконного обігу наркотиків; контрабанди товарів; торгівлі людьми та вогнепальною зброєю; економічних злочинів у сфері оподаткування; підробки документів та ін.

Відповідно до положень ст. 76 ("Законодавство та процедури") Угоди про асоціацію з ЄС Сторони домовилися щодо відповідності їхнього торговельного і митного законодавства, як принципового питання, уніфікації та ефективності застосування його положень і процедур в напрямку пропорціональності, прозорості, передбачуваності, недискримінаційності, об'єктивності та забезпечення захисту і сприяння законній торгівлі, запобігання шахрайству, застосування міжнародних документів, що використовують у митній справі і торгівлі, котрі розроблені Всесвітньою митною організацією/ВМО, Світовою організацією торгівлі/ СОТ, ін., а також керівних принципів ЄС, таких як Митні прототипи (стандарти).

Митні прототипи [11] покликані допомогти покращити і розвинути оперативні й адміністративні можливості митних служб за допомогою встановлення стандартів для досягнення, визначених у 19 ключових сорерах, а також їх показників, що піддаються вимірюванню.

Для формування моделі організаційного забезпечення ОРД в митній службі України необхідно застосовувати Стандарт 12 (“Слідча і правоохоронна діяльність") 3 Митних прототипів (далі - Стандарт 12).

Метою Стандарту $12 є$ створення ефективної і раціональної митної служби, здатної виявляти, запобігати і розслідувати митні правопорушення, акти шахрайства, а також готувати справи для притягнення правопорушників до відповідальності. Така митна служба має бути доволі гнучкою, щоб реагувати на стратегію, засновану на оперативній інформації, новітніх методах цілеспрямованої оцінки ризиків та сучасної технології, здатної забезпечувати надходження доходів і захищати суспільство. Ця митна служба має також забезпечувати дотримання національного та міжнародного законодавства. У переліку стратегічних завдань Стандарту 12 передбачені:

- розробка універсальної правової бази, яка надає митні повноваження, дає змогу обмінюватися інформацією та використовувати інформацію, а також поширюється на митне співробітництво;

- створення організаційних та оперативних можливостей, які дали б змогу ефективно запобігати, виявляти і розслідувати шахрайство в митній справі;

- налагодження і розвиток самостійного співробітництва на політичному та оперативному рівнях, між відділами, з іншими правоохоронними органами (наприклад, поліцією, слідчими структурами, прокуратурою) і судами, а також розвиток міжнародного співробітництва та зв'язків з торговими організаціями і громадськістю;

- створення систем управління, інформаційних технологій, роботи з кадрами та навчання, які дали б змогу реалізовувати слідчі і правоохоронні функції;

- забезпечення відповідної матеріальної бази, обладнання, інфоормаційних технологій і стандартів безпеки в інтересах слідчої і правоохоронної функції.

Комплекс організаційних заходів, спрямованих на можливість забезпечення оперативно-розшукової діяльності (ОРД) в митній службі України, що заснований на завданнях та показниках їх досягнення Стандарту 12 Митних прототипів, подано у табл. 1. 


\section{Завдання та показники їх досягнення 3 організаційного забезпечення ОРД в митній службі України}

\begin{tabular}{|c|c|c|}
\hline № & Завдання & Показники \\
\hline 1 & 2 & 3 \\
\hline \multicolumn{3}{|c|}{ Правова основа } \\
\hline 1 & $\begin{array}{l}\text { Забезпечення національним митним законодавством відпо- } \\
\text { відних повноважень для допиту, огляду, затримання, аре- } \\
\text { шту, конфіскації й обшуку стосовно осіб, товарів, транспорт- } \\
\text { них засобів, документів, облікових записів і приміщень. }\end{array}$ & $\begin{array}{l}\text { - Повноваження митних органів визначено законодав- } \\
\text { ством } \\
\text { • Повноваження реалізуються на практиці }\end{array}$ \\
\hline 2 & $\begin{array}{l}\text { Забезпечення національним законодавством раціональ- } \\
\text { ного обміну інфоомацією між митними та іншими зацікав- } \\
\text { леними урядовими органами, з урахуванням вимог щодо } \\
\text { захисту даних в плані обміну інформацією. }\end{array}$ & \begin{tabular}{|l} 
•Національне законодавство захищає особисті дані в \\
ході обміну інформацією, в тому числі й особистими да- \\
ними, між відповідними урядовими органами в встанов- \\
лених ситуаціях
\end{tabular} \\
\hline 3 & $\begin{array}{l}\text { Забезпечення національним законодавством надання } \\
\text { інформації на основі міжнародних угод з митних питань } \\
\text { і дозвіл ефективно використовувати інформацію, отрима- } \\
\text { ну відповідно до таких угод. }\end{array}$ & \begin{tabular}{|l} 
•Національне законодавство дозволяє обмінюватися ін- \\
фрормацією, в тому числі і особистими даними, з відповід- \\
ними органами інших країн на підставі міжнародних угод \\
•lнформація, отримана на базі такого обміну інформ- \\
цією, може бути ефективно використана відповідно до \\
національного законодавства
\end{tabular} \\
\hline 4 & $\begin{array}{l}\text { Наявність правової бази, яка передбачає митне співро- } \\
\text { бітництво з сусідніми державами, країнами, що представ- } \\
\text { ляють важливих торговельних партнерів, або країнами, } \\
\text { щодо яких неодноразово порушуються митні правила. }\end{array}$ & $\begin{array}{l}\text { - Аналізується потреба у співпраці з певними іншими } \\
\text { країнами } \\
\text { •Укладено договори про взаємодопомогу з митних питань } \\
\text { •Угоди дозволяють обмінюватися особистими даними } \\
\text { та застосовувати сучасні методи розслідування (такі, як } \\
\text { “контрольована поставка") }\end{array}$ \\
\hline \multicolumn{3}{|c|}{ Методи роботи } \\
\hline 5 & $\begin{array}{l}\text { Створення, розвиток і регулярне оновлення універсаль- } \\
\text { ної системи оперативної інформації та інформації для } \\
\text { співробітників, що займаються слідчою та правоохорон- } \\
\text { ною діяльністю, з метою обміну оперативною інформа- } \\
\text { цією з іншими правоохоронними відомствами на базі } \\
\text { національного законодавства та меморандумів про вза- } \\
\text { єморозуміння. }\end{array}$ & \begin{tabular}{|l} 
- Система створена \\
•Система і національне законодавство дозволяють на- \\
давати інформацію іншим правоохоронним відомствам \\
•Підписані і реалізуються Меморандуми про взаємопо- \\
розуміння (далі - МпВ) або угоди з іншими відомствами \\
щодо надання інформації \\
•Встановлено процедури введення та оновлення інфор- \\
мації в системі
\end{tabular} \\
\hline 6 & $\begin{array}{l}\text { Створення оперативних груп, в обов'язки яких входити- } \\
\text { ме збір і аналіз інформації, а також надання актуальної } \\
\text { інфрормації і даних про тенденції співробітникам, які за- } \\
\text { ймаються розслідуваннями і правозастосуванням }\end{array}$ & \begin{tabular}{|l} 
• Створено оперативні групи \\
• Їх учасники пройшли належну підготовку \\
•Встановлено порядок надання інформації такими група- \\
ми співробітників, які займаються слідчою та правоохо- \\
ронною діяльністю
\end{tabular} \\
\hline 7 & $\begin{array}{l}\text { Створення груп експертів і мобільних груп для роботи на } \\
\text { всій митній території з метою проведення правоохоронної } \\
\text { діяльності. }\end{array}$ & $\begin{array}{l}\text { •Створено групи експертів (група реагування або спільні } \\
\text { слідчі групи) } \\
\text { • Створено мобільні групи } \\
\text { •Учасники таких груп пройшли належну підготовку }\end{array}$ \\
\hline 8 & $\begin{array}{l}\text { Створення і робота матеріальної бази для отримання да- } \\
\text { них та інформації (наприклад, Інтернет, електронна пошта, } \\
\text { доступ до відповідних баз даних та інформації онлайн). }\end{array}$ & • Згадана матеріальна база функціонує \\
\hline 9 & $\begin{array}{l}\text { Належне і гнучке реагування на тенденції і загрози (на- } \\
\text { приклад, тероризм, матеріали подвійного призначення, } \\
\text { хімікати, зброю, відмивання грошей, порушення прав ін- } \\
\text { телектуальної власності). }\end{array}$ & $\begin{array}{l}\text { • Є плани дій на випадок кризових ситуацій } \\
\text { •Наявні гнучкі ресурси, які відповідають новим пріоритетам }\end{array}$ \\
\hline \multicolumn{3}{|c|}{ Співробітництво } \\
\hline 10 & $\begin{array}{l}\text { Впровадження тісних робочих зв'язків, включаючи регу- } \\
\text { лярні зустрічі й обмін інформацією, з судами й іншими } \\
\text { правоохоронними відомствами з метою забезпечити на- } \\
\text { лежний та ефективний розгляд спроб здійснення і вчи- } \\
\text { нення правопорушень, приділити належну увагу серйоз- } \\
\text { ності і наслідкам таких правопорушень. }\end{array}$ & \begin{tabular}{|l} 
- Встановлено тісні робочі зв'язки з поліцією та іншими \\
органами, задіяними в судовому переслідуванні \\
- Методи співпраці узгоджені і за можливості фрормально \\
закріплені у вигляді письмових угод. \\
- Відсутні правові перешкоди для ефективної співпраці з \\
названими органами
\end{tabular} \\
\hline
\end{tabular}




\begin{tabular}{|c|c|c|}
\hline 1 & 2 & 3 \\
\hline 11 & $\begin{array}{l}\text { Регулярний обмін інформацією між національними та } \\
\text { міжнародними органами. }\end{array}$ & \begin{tabular}{|l} 
•За необхідності обмін інформацією здійснюється з на- \\
ціональними і міжнародними партнерами на регулярній \\
основі, тобто без запитів і в установлені терміни (щом- \\
сяця, щокварталу тощо)
\end{tabular} \\
\hline 12 & \begin{tabular}{|l} 
Здійснення відповідно до національного законодавства \\
спеціальних форм співпраці, що стосуються транскордон- \\
них дій (наприклад, переслідування по гарячих слідах, \\
спільне спостереження за кордоном, спільні операції), з \\
метою їх недопущення, розслідування і судового переслі- \\
дування порушень митного законодавства.
\end{tabular} & $\begin{array}{l}\text { • Національне законодавство і міжнародні правові інстру- } \\
\text { менти дозволяють здійснювати згадані форми співпраці } \\
\text { • Такі фоорми співпраці застосовуються в разі потреби }\end{array}$ \\
\hline 13 & $\begin{array}{l}\text { Підписання Меморандумів про взаєморозуміння (МпВ) з } \\
\text { основними торговими компаніями, транспортними опера- } \\
\text { торами і асоціаціями. }\end{array}$ & $\begin{array}{l}\text { - Визначено торгові компанії, які могли б надавати мит- } \\
\text { ниці істотну допомогу в зборі оперативних даних } \\
\text { - } 3 \text { торговими компаніями підписані МпВ } \\
\text { - МпВ застосовують і регулярно переглядають на базі } \\
\text { двосторонніх зв'язків з кожною конкретною компанією }\end{array}$ \\
\hline 14 & $\begin{array}{l}\text { Здійснення на регулярній основі внутрішньовідомчих } \\
\text { зв'язків і співпраці між слідчими і правоохоронними струк- } \\
\text { турами, а також іншими зацікавленими підрозділами (на- } \\
\text { приклад, за допомогою нарад, захищеного вебсайту та } \\
\text { спільної роботи). }\end{array}$ & $\begin{array}{l}\text { - ІІнують чіткі інструкції, наприклад, внутрішні установ- } \\
\text { ки, що описують способи і методи взаємовідносин між } \\
\text { слідчими / правоохоронними підрозділами та іншими за- } \\
\text { цікавленими підрозділами } \\
\text { • Є інструменти / засоби, що дають змогу здійснювати } \\
\text { ефективний зв'язок між згаданими підрозділами }\end{array}$ \\
\hline 15 & \begin{tabular}{|l|} 
Створення центрального координаційного органу, який \\
відповідав би за міжнародне співробітництво
\end{tabular} & $\begin{array}{l}\text { • В організаційній структурі митниці є підрозділ / відділ, } \\
\text { який відповідає за відправку і обробку запитів про надан- } \\
\text { ня допомоги з митних питань }\end{array}$ \\
\hline 16 & $\begin{array}{l}\text { Наявність механізмів, за допомогою яких населення мо- } \\
\text { гло б надавати в митні органи інфрормацію про порушен- } \\
\text { ня, пов'язані з митними питаннями. }\end{array}$ & \begin{tabular}{|l} 
- $Є$ засоби, наприклад, гаряча телефонна лінія, що \\
дають змогу громадськості надавати митниці інформа- \\
цію про порушення \\
- Існують можливості заохочення громадськості за на- \\
дання митниці інформації, громадськість поінфрормована \\
про такі можливості
\end{tabular} \\
\hline \multicolumn{3}{|c|}{ Керівництво, персонал і підготовка } \\
\hline 17 & $\begin{array}{l}\text { Створення загальної для всієї адміністрації стратегії } \\
\text { щодо слідчих і правоохоронних питань, забезпечення ії } \\
\text { доступності для всіх співробітників, які займаються слід- } \\
\text { чими і правоохоронними питаннями, і моніторингу керів- } \\
\text { ництвом її застосування. }\end{array}$ & $\begin{array}{l}\text { - Стратегія існує і регулярно оновлюється } \\
\text { •Стратегія доступна для співробітників слідчих/ право- } \\
\text { охоронних структур } \\
\text { • Слідчі / правоохоронні підрозділи залучаються до під- } \\
\text { готовки проектів / регулярного оновлення стратегії }\end{array}$ \\
\hline 18 & $\begin{array}{l}\text { Створення систем підготовки керівного складу та навчан- } \\
\text { ня кадрів зі слідчих і правоохоронних питань і їх коорди- } \\
\text { нація з іншими правоохоронними відомствами. }\end{array}$ & \begin{tabular}{|l} 
- Здійснюється підготовка як керівників, так і рядових спів- \\
робітників, які працюють в слідчій / правоохоронній сфері \\
- Підготовка заснована на програмах підготовки, в яких \\
враховується реальна стратегія в слідчій / правоохорон- \\
ній сфері \\
• Навчальні програми складають і виконують у співпраці \\
з іншими правоохоронними органами
\end{tabular} \\
\hline \multicolumn{3}{|c|}{ Матеріальна база, обладнання та комп'ютеризація } \\
\hline 19 & $\begin{array}{l}\text { Впровадження радіо-телекомунікаційних засобів разом з } \\
\text { обладнанням для спостереження та огляду, безпосеред- } \\
\text { ньо доступних для митниці і таких, що забезпечують під- } \\
\text { вищення оперативної ефективності. }\end{array}$ & $\begin{array}{l}\text { • Радіо-телекомунікаційні засоби є в наявності } \\
\text { - Устаткування для спостереження та огляду є в наявності } \\
\text { - Співробітники пройшли курс навчання з використання } \\
\text { обладнання }\end{array}$ \\
\hline 20 & $\begin{array}{l}\text { Комп'ютеризація слідчих і правоохоронних систем за } \\
\text { можливості і необхідності. }\end{array}$ & \begin{tabular}{|l} 
- Інформаційно-комунікаційна технологія використову- \\
ється для підтримки слідчої / правоохоронної структури \\
за можливості і необхідності
\end{tabular} \\
\hline
\end{tabular}


На особливу увагу заслуговує те, що Стандартом 12 (“Слідча і правоохоронна діяльність”) Митних прототипів слідча діяльність, поряд з оперативно-розшуковою діяльністю, віднесена до компетенції митних органів.

Тож, з погляду інтересів митної безпеки, передбачене Стандартом 12, наділення митної служби одночасно оперативними та слідчими повноваженнями, покликане забезпечити цілісність та ефективність правоохоронної місії державної митної служби.

3 урахуванням вищенаведеного обсягу завдань, призначеного до виконання осучасненою, згідно з міжнародними стандартами, митною службою України, має відбутися відповідна структурна трансформація ії правоохоронних підрозділів.

Чинна на сьогодні структура правоохоронних підрозділів митної служби, в умовах недостатності її правового статусу, позбавлена складових елементів оперативнорозшукового, слідчого та розвідувального спрямування.

Застосування у назвах підрозділів митної служби терміна "оперативний” певним чином зміцнює ії правоохоронний імідж та заохочує до функціонального вдосконалення, але не компенсує відсутність інституційних важелів, необхідних для самостійного та повноцінного здійснення митними органами оперативно-розшукових заходів, що наведені у Законі про ОРД [7].

Відтак після приведення норм законодавства України відповідно до положень Конвенції Найробі, Митних прототипів ЄС, Резолюцій ВМО “Щодо важливості розвідувальних даних для підтримки діяльності з митного правозастосування", “Про роль митниці в контексті безпеки” виникнуть підстави для структурної трансформації правоохоронного блоку митної служби держави.

Висновки. Підсумовуючи вищевикладене, варто наголосити на ключових компонен- тах організаційно-структурного забезпечення оперативно-розшукової діяльності вітчизняних митних органів. А саме на необхідності:

1. Усунення дисбалансу між правоохоронними завданнями та повноваженнями митних органів України шляхом законодавчого розширення їхнього правового мандату.

2. Організації митної розвідувальної діяльності відповідно до Резолюцій ВМО від 24 червня 1992 року “Щодо важливості розвідувальних даних для підтримки діяльності з митного правозастосування", “Про роль митниці в контексті безпеки” (Резолюція Пунта-Кана) [2].

3. Застосування митними органами всього спектру сучасних прийомів виявлення та розслідування, обміну розвідданими, контрольованих поставок, пошукових собак та обладнання.

4. Впровадження заходів, спрямованих на застосування мультиагентського підходу в сфері боротьби з незаконним обігом наркотиків, відмиванням грошей, торгівлею вогнепальною зброєю, контрабандою та шахрайством.

5. Міжнародної, міжвідомчої правоохоронної співпраці з метою залучення митних органів до планування та проведення спеціальних операцій проти транскордонної злочинності.

6. Долучення, за встановленою процедурою, Додатків IV, IX, X, XI Конвенції Найробі до законодавства України з метою посилення правового підґрунтя для набуття митними органами нашої держави повноважень на здійснення ОРД.

7. Застосування у митній справі згідно з ст. 76 Угоди про асоціацію з ЄС керівних принципів $€ C$, таких як Митні прототипи (Customs blueprints) [11], для забезпечення здійснення митними органами України слідчої та оперативно-розшукової діяльності 3 метою досягнення цілісності й ефективності правоохоронної місії ДМСУ. 
8. Структурної трансорормації правоохоронних підрозділів митної служби України відповідно до потреб розвідувальної, слідчої, оперативно-розшукової діяльності.

\section{Список використаних джерел}

1. Антонов К.В., Варава В.В. Збільшення правоохоронних повноважень митних органів у контексті розвитку митного та оперативно-розшукового законодавства. Вісник Академії митної справи України. 2010. №1(4). URL : http://webcache.googleusercontent.com/ search?q=cache:6RMTebdMMwcJ:www.irbisnbuv.gov.ual.

2. Разумова О. Забезпечення митної безпеки України з урахуванням зарубіжного досвіду. Підприємництво, господарство і право. 2019. № 5. C. 166-169.

3. Дорофреєва Л.М. Окремі аспекти реалізації захисної функції митних органів України. Науковий вісник публічного та приватного права. 2017. Вип. 2. С. 124-129.

4. Резолюція Ради митного співробітниитва щодо важливості розвідувальних даних для підтримки діяльності з митного правозастосування: міжнародний документ від 24.06.1992 /База даних "Законодавство України". BP України. URL : http://www.wcoomd.org///media/ wco/public/global/pdf/ about-us/legal-nstruments/ resolutions/importance of intelligence.pdf?la.

5. Резолюція Пунта-Кана Комісії з питань політики Всесвітньої митної організації про роль митниці в контексті безпеки, грудень 2015: міжнародний документ /База даних "Законодавство України". BP України. URL : http:// www.wcoomd.org/en/about-us/legal-instruments/ resolutions.aspx.

6. Міжнародна конвенція про взаємну адміністративну допомогу у відверненні, розслідуванні та припиненні порушень митного законодавства від 09.06.1977 /База даних “Законодавство України". ВP України. URL : http:// zakon.rada.gov.ua/laws/show/995 926\#Text.
7. Про оперативно-розшукову діяльність. Закон України від 18.02.1992 № 2135-XII. URL : http://zakon.rada.gov.ua/laws/show/2135-12.

8. Про міжнародні договори України. Закон України від 29.06.2004 № 1906. URL : http:// zakon.rada.gov.ua/go/1906-15.

9. Митний кодекс України від 13.03.2012 № 4495-VI. URL : http://zakon.rada.gov.ual go/4495-17.

10. Угода про асоціацію між Україною, з однієї сторони, та Європейським Союзом, Європейським співтовариством з атомної енергії і їхніми державами-членами, з іншої сторони : міжнародний документ від 27. 06. 2014/База даних “Законодавство України”. ВР України. URL : http://zakon.rada.gov.ua/laws/show/984_011\#Text.

11. Митні прототипи : міжнародний документ, 2020 /База даних “Законодавство України". ВР України. URL : http:// ec.europa.eu/ taxation_customs/sites/taxation/ files/resources/ documents/common /eutraining/customs blueprintsru.pdf

\section{References}

1. Antonov, K. V., Varava, V. V. (2010). Zbilshennia pravoohoronnyh povnovagen mytnyh organiv u konteksti rozvytky mytnogo ta operatyvnorozshukovogo zakonodavstva [Increasing the law enforcement powers of customs authorities in the context of the development of customs and operational-search legislation]. Visnyk Akademii mytnoi spravy Ukrainy - Bulletin of the Akademy of Customs of Ukraine, 1(4). Available at: http:/l webcache.googleusercontent.com/search?q =cache:6RMTebdMMwcJ:www.irbis-nbuv.gov.ual.

2. Razymova, O. (2010). Zabezpechennia mytnoi bezpeky Ukrainy z urahuvanniam zarubignogo dosvidu [Ensuring customs security of Ukraine taking into account foreign experience]. Pidpryiemnytstvo, gospodarstvo i pravo - Entrepreneurship, economy and law, 5, 166-169 [in Ukraine].

3. Dorofeieva, L. M. (2017). Okremi aspekty realizatsii zahysnoi funktsii mytnyh organiv Ukrainy [Some aspects of the implementation of the protec- 


\section{МИТНА СПРАВА}

tive function of the customs authorities of Ukraine]. Naukovyi visnyk publichnogo ta pryvatnogo prava Scientific Bulletin of Public and Private Law, 2, 124-129 [in Ukraine].

4. Rezoliutsia Rady mytnogo spivrobitnytstva schodo vaglyvosti rozviduvalnyh danyh dlia pidtymky diialnosti z mytnogo pravozastosuvannia: mignarodnyi dokument [Customs Cooperation Council Resolution on the importance of intelligence to support customs enforcement activities: international document] 24. 06. 1992. Baza danuh "Zakonodavstvo Ukrainy", VR Ukrainy - Database "Legislation of Ukraine", Verkhovna Rada of Ukraine. Available at: http://www.wcoomd.org/-/media/wco/ public/global/pdf/about-us/legal-nstruments/ resolutions/importance of intelligence.pdf?la.

5. Rezoliutsia Pynta-Kana Komisii z pytan polityky Vsesvitnoi mytnoi organizatsii pro rol mytnytsi $\checkmark$ konteksti bezpeky, gruden 2015: mignarodnyi dokument [Resolution of the Punta-Cana Commission of the World Customs Organization on the role of customs in the context of security, December 2015: international document]. Baza danuh "Zakonodavstvo Ukrainy", VR Ukrainy - Database "Legislation of Ukraine", Verkhovna Rada of Ukraine. Available at: http://www.wcoomd.org/en/about-us/ legal-instruments/resolutions.aspx.

6. Mignarodna konventsia pro vzaiemnu administratuvnu dopomogu u vidverneni, rozsliduvanni, ta prypynenni poryshen mytnogo zakonodavstva vid 09.06.1977 [International convention on mutual administrative assistance in the prevention, investigation and cessation of violations of Customs Law]. (1977, June, 9). Baza danuh "Zakonodavstvo Ukrainy", VR Ukrainy - Database "Legislation of Ukraine», Verkhovna Rada of Ukraine. Available at: http:// zakon.rada.gov.ua/laws /show 1995 926\#Text.
7. Pro operatyvno-rozshukovu diialnist. Zakon Ukrainy vid 18.02.1992 № 2135-XII, [About operative-search activity. Law of Ukraine]. (1992, February, 13). Available at: http://zakon.rada.gov.ual laws/show/2135-12.

8. Pro mizhnarodni dogovory Ukrainy. Zakon Ukrainy vid 29.06.2004 № 1906, [About international agreements of Ukraine. Law of Ukraine]. (2004, June, 29). Available at: http://zakon.rada.gov.ual go/1906-15.

9. Mytnyi kodeks Ukrainy. Zakon Ukrainy vid 13.03.2012 № 4495-VI [Customs Code of Ukraine. Law of Ukraine]. (2012, March, 13). Available at: http://zakon2.rada.gov.ua/laws/show/4495-17.

10. Ugoda pro asotsiatsiiu mig Ukrainoiu, $z$ odniiei storony, ta Yevropeiskym Soiuzom, Yevropeiskym spivtovarystvom z atomnoi energii i ihnimy dergavamy-chlenamy, z inshoi storonu: mignarodnyi document vid 27. 06. 2014 [Association Agreement between Ukraine, of the one part, and the European Union, the European Atomic Energy Community and their Member States, of the other part: international document dated June 27, 2014]. Baza danuh "Zakonodavstvo Ukrainy", VR Ukrainy Database "Legislation of Ukraine", Verkhovna Rada of Ukraine. Available at: http://zakon.rada.gov.ua/ laws/show/984 011\#Text.

11. Mytni prototypy: mizhnarodnyi document, 2020 [Customs blueprints: international document, 2020]. Baza danyh "Zakonodavstvo Ukrainy", VR Ukrainy - Database "Legislation of Ukraine", Verkhovna Rada of Ukraine. Available at: http:// ec.europa.eu/taxation customs/sites/taxation/ files/resources/documents/common/eutraining/ customs blueprintsru.pdf.

Стаття надійшла до редакції 28.11.2020. 